\section{Some Solutions in Local Development Through Public Projects. The Case of Vorona Commune from Botoşani County}

Petronela SCUTARIU1, Larisa-Bianca LITEANU2

${ }^{1}$ Lecturer PhD, "Ştefan cel Mare" University of Suceava, Faculty of Law and Administrative Sciences, Suceava, Romania;petronela.scutariu@ffdsa.usv.ro

2 Master Student, "Ştefan cel Mare" University of Suceava, Faculty of Law and Administrative Sciences, Suceava, Romania; liteanu.larisa@yahoo.com
Abstract: In order to improve the socio-economic conditions at the community level, local development efforts are needed, within which it is necessary to contract and implement adequate public projects. Through its content, this paper aims to analyze the process of two development public projects to highlight the results - asphalted communal roads and rehabilitated and modernized secondary school - on the quality of life of members of the local community in Vorona Commune, Botosani County. By asphalting some roads in the commune, the access of the locals to different units of public interest has been improved, as well as the attraction of possible investors in the area. Carrying out the rehabilitation and modernization works of the school determined the improvement of the educational infrastructure, the optimization of the conditions for the teaching process, the increase of the schoolchildren's comfort, these effects finally materializing in the improvement of the school results.

Keywords: local development, public projects, technical-edilitary endowment, investment objectives, asphalting of communal roads, school rehabilitation and modernization works.

How to cite: Scutariu, P., \& Liteanu, L-.B. (2021). Some Solutions in Local Development Through Public Projects. The Case of Vorona Commune from Botoşani County. European Journal of Law and Public Administration, 8(1), 48-60. https://doi.org/10.18662/elipa/8.1/148 


\section{Introduction}

The topic of local development has various defining tendencies, without a universally valid explanation in the literature. Beyond this minus, two criteria can be identified to clarify the subject of local development: the local community and its needs; changes taking place within the local. The first criterion refers to those who need to benefit from development, and the second focuses on the effects of changes that occur as a result of local development (Sekuła, 2020).

Development aims to improve the quality of life of citizens, the purpose of any development policy not only to increase economic growth, but being closely linked to the notion of quality of life. To ensure local development, development projects aim to improve the socio-economic conditions of citizens (Odoom et al., 2018).

In this context, the purpose of this paper is to analyze the process of two development public projects to highlight the results on the quality of life of members of the local community, with specialization in Vorona Commune in Botosani County.

\section{Descriptive elements regarding the technical-edilitary endowment of Vorona commune from Botoşani County}

Vorona commune is located in a hilly area, in the southwestern part of Botoşani county, not far from the confluence of the Siret river with the Suceava river, $22 \mathrm{~km}$ away from Botoşani municipality and $14 \mathrm{~km}$ from Liteni town in Suceava county. It is one of the largest communes in Botoşani County with an area of 8,656 ha, with a population of 7,492 inhabitants in the 6 component villages: Vorona, Icuşeni, Joldeşti, Poiana, Vorona-Mare, Vorona-Teodoru.

Road network. The connection of Vorona commune with the national road DN 28B (towards Botoşani) is made through DJ 208 FălticeniBotoşani. The roads on the territory of the commune total $185.46 \mathrm{~km}$, of which $42 \mathrm{~km}$ are communal roads, $49.8 \mathrm{~km}$ village roads and $93.6 \mathrm{~km}$ neighboring roads.

Drinking water supply network. At present, the supply of drinking water in Vorona commune is made from household wells. In this sense, the 
project for the establishment of the water supply system of the commune is in the execution phase.

Electricity supply network. Vorona commune is fully electrified, all households being connected to the electricity grid. The length of the electricity network is $114 \mathrm{~km}$. Recently, the public lighting system has been improved with more than 2,000 lighting fixtures with low energy consumption.

Education. The education system of Vorona commune includes 11 kindergartens, a primary school, 5 secondary schools and a technological high school with high school and vocational education classes, a modern Documentation and Information Center. The school population includes about 1,500 children. Their education is provided by over 140 teachers, engineers, foremen and instructors.

Social assistance. In the field of social assistance, there is a specialized service within the City Hall and includes three specialized inspectors and a community assistant. Currently, 74 disabled people and 40 people with a guaranteed minimum income are registered in the City Hall records.

Healthcare. Within the new mayor's office, there are two spaces for healthcare services: a medical office and a permanent center. Health services are provided by two family doctors and 5 other medical staff. In the center of Vorona village there is a human pharmacy, and in Vorona Mare there is the Sanitary-Veterinary Unit, with a veterinarian and two staff with secondary education.

\section{Asphalt investment objective DC 55g (dc $386+$ ds 316), DC 812 and DC638, Vorona commune, Botoşani County}

The location of the investment includes the villages of Poiana and Icuşeni in Vorona locality. The connection with the county seat municipality is made through the county road DJ 208C.

Carrying out the works. The project definition stage - By asphalting these communal roads, the infrastructure representing the road traffic routes will be consolidated, ensuring the capacity to cover the traffic needs at local level. The proposed communal roads are not asphalted, they require an urgent arrangement, as they are impracticable especially in rainy weather (see Figure 1): 


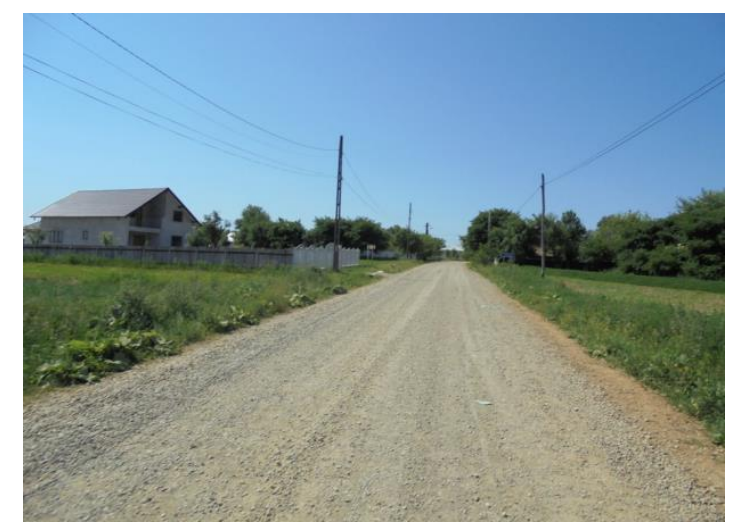

Fig. 1. DC 55G road before the start of the asphalting works

Source: Authors' own conception

In sensitive areas, there was periodic clogging with dusty-clay material, non-corrosive, which allowed water infiltration into the body of the road, the consequence being uneven settlements, due to the dislocation of the material and chaotic restoration, by its engagement by vehicles and uncontrolled dispensing. Rainwater collection and drainage devices (ditches and gutters) are not provided. In rainy weather (spring, autumn), a large part of the communal roads become impassable, and access becomes possible only on foot, but also difficult.

The communal roads ensure the access of the inhabitants from Icusseni and Poiana villages to the units of public interest such as: school; the police station; sanitary units; churches; Cultural House.

The roadway and sidewalks are not designed so that the roads are uniform for traffic comfort. The road structure before the start of the works had a weak hardening, the unevenness being danger points for traffic safety.

Project planning stage - Technical plan: The technical condition of the roads negatively influences the economic, social and cultural life of the inhabitants of Icuşeni and Poiana villages. In July 2019, the contract for the design and execution of works was signed. After the technical reception, the project was verified by a project certificate, and then the technical documentation regarding the building permit will be made.

By the Decision of the Vorona Local Council no. 73 of October 28, 2019, the updated general Estimate for the investment objective "Asphalting 
DC 55G (DC $386+$ DS 316) and DC 638, Vorona commune, Botoşani county" was approved, as well as the technical-economic indicators of the investment objective "Asphalting DC 55G (DC 386 + DS 316), DC 812 and DC 638, Vorona commune, Botoşani county", crossing the villages of Icuşeni and Poiana, belonging to Vorona commune on a total length of 4,760 km (Vorona Local Council, 2019a).

In order to highlight the existing situation in the field, studies have been carried out which show that communal roads have irregularities and deformations, transverse slopes are not ensured, which makes the drainage of water to be done properly, thus leading to road surface degradation.

The documentation is accompanied by opinions and agreements, such as: the decision of the chief authorizing officer on the need and timeliness of the investment; urbanism certificate; environmental agreement; other opinions or agreements associated with the investor and the legislation in force.

Estimates of the labor force employed by making the investment: 1. Number of jobs created in the execution phase. For the execution phase, a need of 20 jobs is estimated during the execution period of 12 months, these being occupied by 10 qualified employees, with an indefinite employment contract, coming from the structure of the executor's staff and 10 new jobs. work during the execution period of 12 months, unskilled workers, seasonal workers from among the locals. 2. Number of jobs created in the operation phase. The supervision and maintenance of the necessary conditions for a good administration, maintenance and operation of roads, concrete ditches, tubular bridges and road signs will be done throughout the year.

Resource plan. The total value of the investment is 5,326,248 lei (including VAT). The investment will be financed from funds from the budget of Vorona commune, Botoşani county, funds attracted from the state budget, as well as from other legally constituted funds - external, multisource, non-reimbursable funds.

The time plan. The investment is estimated for a period of 12 months and the duration of the investment is expected to be a maximum of 18 months from the date of contacting the winning contractor, according to the provisions of Law 98/2016 on public procurement. The time horizon for 
performing the cost-benefit analysis is 30 years according to the recommendations (minimum 25 years) (Romanian Parliament, 2016).

Project implementation stage. In November 2019, all the factors involved in the project were convened, namely: the builders, the site manager, the designer and the beneficiary. The emplacement was handed over and landmarks were established. After completing all the necessary documents, in mid-November work began on the foundation. Due to the cold season, the works were stopped. With the increase of temperatures, in April 2020, the asphalting works were resumed, pouring the asphalt carpet, during this stage the unclogging of the ditches was also carried out (see Figure 2):

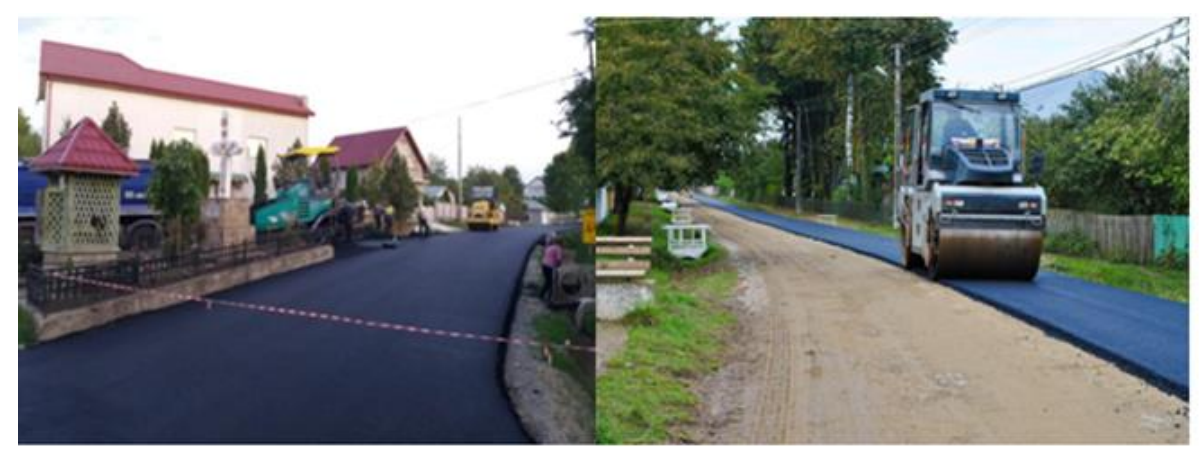

Fig. 2. DC 638 road during modernization and asphalting works

Source: Authors' own conception

Project completion stage. The achievement of this objective also involved the arrangement of intersections with side roads, the execution of road signs, the execution of concrete ditches, road ditches, transverse bridges, thus ensuring the taking over and directing of rainwater.

When carrying out the asphalting works of the roads DC 55G (DC 386 + DS 316), DC 812 and DC 638, it was not necessary to occupy new land surfaces, the works being carried out on the existing embankment of the respective communal roads (see Figure 3).

By carrying out the asphalting works, the area where the road is being carried out did not suffer any additional negative effects compared to the situation prior to the start of the works. 
On the contrary, some favorable effects can be highlighted both from an economic and social point of view, as well as from environmental factors by reducing the degree of pollution and the noise level.

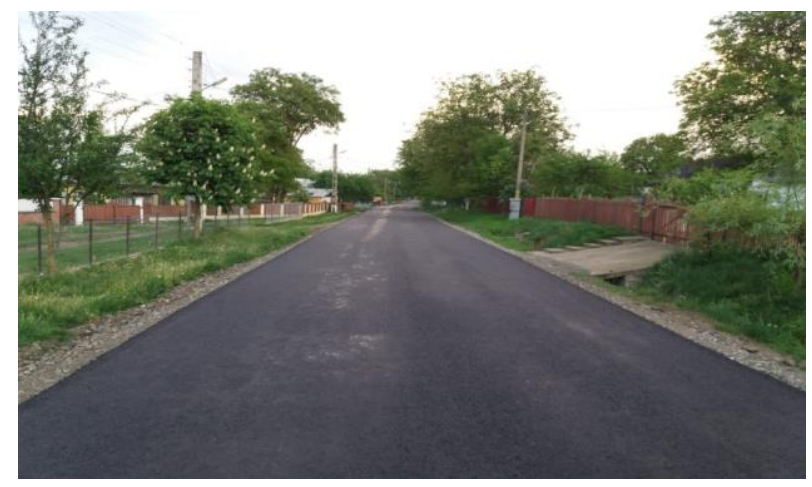

Fig. 3. Asphalting works

Source: Authors' own conception

\section{The investment objective of rehabilitation and modernization}

\section{"Alexandru Ioan Cuza" school, Vorona location, Botoşani County}

Investment location. The construction site of the "Alexandru Ioan Cuza Vorona" Gymnasium School is located in the built-up area of Vorona village, Vorona commune, a building belonging to the public domain of the commune. The land is not located in the protected area or with a final construction ban, with an area of 5,535 sqm, composed of 3,337 sqm of use category and 2,198 sqm of arable land. The construction is part of the public inventory of Vorona commune, the building not being included on the list of historical monuments.

Carrying out the works. Project definition stage. The building has an obvious general physical wear and tear, requiring the replacement and consolidation of several elements. The degradations identified both at the level of finishes and at the level of structural elements are caused both by the duration of operation and by weathering. Through the investigations carried out, the construction had the following deficiencies: degradation of the plaster on the plinth; degradation of exterior finishes; degradation of interior finishes; roof degradation; cracks in the structural elements. 
The existing construction consists of a building built in the 1960s and a room for the thermal power plant built in 2007. The resistance structure consists of load-bearing walls of solid brick masonry and wooden floors. The floor above the ground floor is of the wooden frame type on the chairs, and the roof is made of tin.

Regarding the access to the main body of the building, it is ensured through the main façade, two other secondary accesses being ensured on the right side façade and the left interior façade respectively.

The school is equipped with toilets inside, but they are not regulated according to the number of children and do not respect the dimensions for people with disabilities.

The school is composed of the following spaces: access hall, three classes with direct access from the hall, teaching materials, chancellery with access to a connection class, secondary hall with access to two classes, bathrooms by gender, bathroom for people with disabilities.

Description of existing installations. The objective benefits from electricity supply, being connected to the existing electricity network in the locality. The lighting of the objective is achieved by luminaires such as ceiling lights and sconces. In general, the electrical installation related to the school shows major degradations and exceeded service life of lighting fixtures, sockets, circuits and panels. Over the years, a series of partial interventions have been made on the interior electrical installations of the building. Some of the lighting fixtures, sockets, accumulators, but insufficient to bring it to the regulations in force, have been replaced. The objective does not benefit from a water supply connection, a natural gas supply connection, as well as a connection to the sewerage network, the wastewater discharge being made by means of a drainable tank.

Project planning - Technical plan. The contract was signed in May 2018, having as objective the realization of the technical project and the execution of the rehabilitation and modernization works of the "Alexandru Ioan Cuza" Gymnasium School, Vorona commune. After the technical project was carried out, it was verified, following that after obtaining the compliance report, the contracting authority - Vorona City Hall to issue the construction permit. 
By the Decision of the Vorona Local Council no. 36 of April 22, 2019, the technical-economic documentation was approved: General estimate regarding the rest to be executed and the technical-economic indicators related to the investment objective Rehabilitation and modernization "Alexandru Ioan Cuza" Gymnasium School, Vorona commune, Botoşani county (Vorona Local Council, 2019b).

The designed solution aims to correlate installations and equipment with the legislation in force on quality requirements in construction: mechanical strength and stability, operational safety, fire safety, hygiene, health and environment, energy-saving and thermal insulation, noise protection.

The documentation will be accompanied in the process of promoting its financing by the following opinions and agreements: the decision of the chief authorizing officer on the need and opportunity of the investment; urbanism certificate; environmental agreement; the opinion of the Inspectorate for Emergency Situations; other opinions or agreements associated with the investor and the legislation in force.

Resource plan. The total value of the investment is 1,146,510.00 lei (including VAT). The investment will be financed from funds from the budget of Vorona Commune, Botoşani County, funds attracted from the state budget, as well as other legally constituted funds - external, multisource, non-reimbursable funds.

Time plan. The estimated duration of the investment is 24 months, and the estimated duration of the execution works is 12 months from the date of contracting with the successful bidder according to the provisions of Law 98/2016 on public procurement (Romanian Parliament, 2016).

Project implementation stage. In April 2019, all the factors involved in the project were convened, namely: the builders, the site manager, the designer and the beneficiary. The emplacement was handed over and landmarks were established.

The rehabilitation and modernization works started in May 2019, until November 2019 the following works were carried out: replacement of the exterior carpentry, change of the roof, replacement of the thermal power plant see Figure 4) 


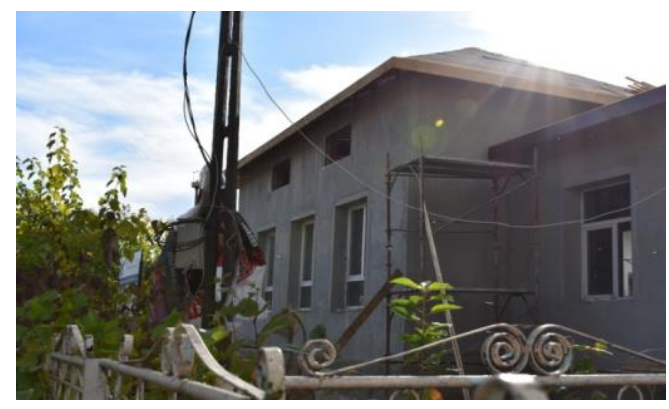

Fig. 4. "Alexandru Ioan Cuza" Gymnasium School at the beginning of modernization works

Source: Authors' own conception

As a result of the extension works, the school is composed of the following spaces: windfang main access, distribution halls classes, 6 classes, chancellery, teaching material, program space "Horn and milk", toilets (two toilets for teachers, toilets girls, toilets boys, group of people with disabilities.

As the cold season intervened, the works were stopped, but with the increase of temperatures, in March 2020 the rehabilitation and modernization works were resumed.

The finalization stage of the project. The building was put into use in July 2020, with the start of the 2020-2021 school year, the school opening its doors to receive students in a much cleaner and modernized environment according to European standards(see Figure no. 5).

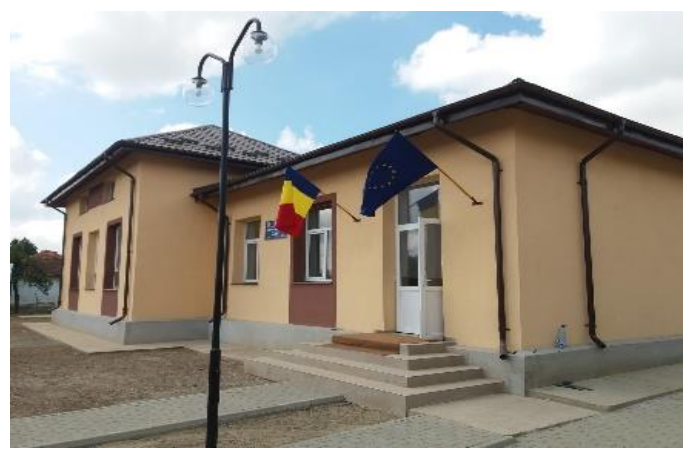

Fig. 5. "Alexandru Ioan Cuza" Gymnasium School at the completion of modernization works

Source: Authors' own conception 
This modernization has ensured, as an economic and social impact, the creation of new jobs, the provision of cultural and social opportunities, with the attraction of schoolchildren in a pleasant and modern educational environment.

As a result of the implementation of the Modernization and Rehabilitation project, the "Alexandru Ioan Cuza" Gymnasium School, the following benefits were obtained: the improvement of the services regarding the development of the school programs; ensuring a recreational environment, optimal for the good development of schoolchildren and preschoolers; improving hygienic-sanitary conditions.

\section{Conclusions}

Based on the above, we can conclude that the approach made possible the analysis of the process of two development public projects highlighting the results - asphalted communal roads and rehabilitated and modernized seondary school - on the quality of life of local community members in the commune Vorona, Botoşani County.

Regarding the technical-edilitary endowment, on the territory of this commune: there is a road network of $185,46 \mathrm{~km}$; the drinking water supply system is in the execution phase; all households are connected to the electricity grid; education is provided by 11 kindergartens, a primary school, 5 secondary schools and a technological high school with high school classes and vocational education; within the City Hall there is a specialized social assistance service; in the field of healthcare, there is a medical office, a permanent center, a human pharmacy and a sanitary-veterinary unit.

The development of the project "Asphalting DC 55G (DC $386+$ DS 316), DC 812 and DC 638 in Vorona locality" has led to improved access for locals to public interest units, such as school, police station, health facilities, churches or cultural center, but also attracting potential investors in the area. Following the execution of the asphalting works, the area on which the communal roads are carried out did not suffer any additional negative effects compared to the situation prior to the beginning of the works. On the contrary, some favorable effects can be highlighted both from an economic and social point of view, but also from environmental factors by 
decreasing the degree of pollution and the noise level. Strengthening local infrastructure can be considered one of the most important supporting factors in the economic development of this area.

By carrying out the project "Rehabilitation and Modernization of Alexandru Ioan Cuza High School in Vorona locality" (Vorona Local Council, 2019b), the local authorities have made efforts to make investments in the local education system. The benefits of this development project are materialized in the improvement of the services regarding the conducting of school curricula; ensuring a recreational environment, optimal for the good development of schoolchildren and preschoolers; improving the hygienicsanitary conditions. This modernization has had an economic and social impact by creating new jobs, providing cultural and social opportunities, attracting schoolchildren in a pleasant and modern educational environment.

Overall, the approach taken in the pages of this paper gives us the opportunity to point out that such development projects are likely to ensure the improvement of the quality of life of the inhabitants of the area. To this end, local authorities should constantly analyze local conditions and the needs of the community in order to identify the most appropriate solutions and make appropriate investments to ensure that local problems are remedied.

\section{References}

Vorona Local Council (2019a). Hotărârea Consiliului Local Vorona nr. 73 din 28 octombrie 2019 privind aprobarea devizulni general actualizat şi a indicatorilor tehnicoeconomici ai obiectivului de investiții ,Asfaltare DC 55G (DC $386+$ DS 316) și DC 638, comuna Vorona, judetul Botosan?' [Decision of the Vorona Local Council no. 73 of October 28, 2019 on the approval of the updated General Estimate and technical-economic indicators of the investment objective "Asphalting DC 55G (DC 386 + DS 316) and DC 638, Vorona commune, Botoşani county"].

Vorona Local Council (2019b). Hotărârea Consiliului Local Vorona nr. 36 din 22 aprilie 2019 privind aprobarea documentatiei tehnico-economice. Deviz general privind restul de executat şi indicatorii tehnico-economici aferente obiectivului de investiții „, Reabilitare şi modernizare Şcoala Gimnazială Alexandru Ioan Cuza, comuna Vorona, judeţul Botosani" [Decision of the Vorona Local Council no. 36 of April 22, 2019 on the approval of the technical-economic documentation General Estimate regarding the rest to be executed and the technical-economic 
Some Solutions in Local Development Through Public Projects. The Case... Petronela SCUTAIRU \& Larisa-Bianca LITEANU

indicators related to the investment objective "Rehabilitation and modernization Alexandru Ioan Cuza Secondary School, Vorona commune, Botoşani county"].

Romanian Parliament (2016). Legea Nr.98/2016 din 19 mai 2016 privind achizițiile publice [Law no. 98/2016 on public procurement]. Monitorul Oficial, Partea I, 390, 23 mai 2016 [Official Gazette, Part I no. 390 of May 23, 2016]. https://lege5.ro/gratuit/geytcnbrgy3a/legea-nr-98-2016-privind-achizitiilepublice

Odoom, D., Mensah, F. K., Opoku, E., Owusu, A. Y. (2018). Sustaining Development Projects within the Local Government System in Ghana: Exploring the Views of Local Authorities and Other Stakeholders in Shama District. International Journal of Innovative Research \& Development, 7(12), 11-20. https://doi.org/10.24940/ijird/2018/v7/i12/DEC18011

Sekuła, A. (2020). Local development - the definition aspect in the 21st century. In Company at the Turn of the 21st Century (pp. 59-64). Politechnika Rzeszowska. https://www.researchgate.net/publication/262854751_Local_developmen t - the definition aspect in the 21st century

Romanian Parliament. (2014). Legea nr. 155 din 12 iulie 2010 politiei locale [Law no. 155 from July 12, 2010, on establishment of Local Police in Romania]. Monitorul Oficial, 399, 8 mai 2014 [Official Gazette of Romania, no. 399 on May 8, 2014]. http://legislatie.just.ro/Public/DetaliiDocument/120615 